\title{
The Effect of Snake Fish Extract (Channa striata) on Post Cesarean Section Wound Status in Postpartum Anemia Mothers
}

\author{
Umi Nur Fajri'), Suharyo Hadisaputro²), Ariawan Soejoenoes ${ }^{2)}$ \\ 1)Applied Midwifery, Graduate Program, School of Health Polytechnics, \\ Ministry of Health Semarang \\ ${ }^{2)}$ School of Health Polytechnics, Ministry of Health Semarang
}

\begin{abstract}
Background: A labor with Sectio Caesarea (SC) will increase mortality rate, which is twice the rate of vaginal delivery. The morbidity rate is also higher in SC delivery due to post-SC wound infection. Post-SC wound healing requires high albumin. This study is intended to determine the effect of snake fish extract on post-SC wound status in postpartum anemia women.

Subjects and Method: This was a true experimental study with randomized control group post-test design. The study was conducted at Hj. Anna Lasmanah Hospital, Banjarnegara, Central Java, in May to June 2018. The population of all post-partum postpartum mothers was anemia. A sample of 30 study subjects was selected by stratified random sampling, consisted of 15 study subjects in intervention and control groups. The dependent variable was post-SC wound. The independent variable was snake fish extract. Post-SC wound was measured by REEDA scales. The data was analyzed by General Linear Model Repeated Measure.

Results: In day-5, post-SC wound in the intervention group (mean $=0.27 ; \mathrm{SD}=0.46$ ) was lower than control group $($ mean $=1.07 ; \mathrm{SD}=0.80)$ and it was statistically significant $(\mathrm{p}=0.002)$.

Conclusion: Channa striata extract can accelerate post-SC wound healing.
\end{abstract}

Keywords: Channa striata extract, wound status, sectio caesarea, anemia

\section{Correspondence:}

Umi Nur Fajri. Applied Midwifery, Graduate Program, School of Health Polytechnics, Ministry of Health Semarang. Email: nurfajriumie@yahoo.co.id. Mobile: 085214594590.

\section{BACKGROUND}

Sectio Caesarea (SC) is a modern operating methods, aims to lowering the morbidity rate and mortality rate in maternal (Sofian, 2011). The World Health Organization (WHO) sets the average standard of SC in a country is around $5-15 \%$ in the world. In Indonesia, childbirth with SC has exceeded the maximum WHO standard of $5-15 \%$ (WHO, 2010).

A delivery with SC action will increase the mortality rate that is twice the rate of vaginal delivery, the rate of morbidity is also higher in delivery SC this is due to infection, blood loss, and damage to internal organs (Kulas et al., 2008). Ninety percents of postoperative morbidity are caused by infection (infection of the uterus or endometritis, voiding devices, and surgical wounds). For a long time, wound healing after SC surgery takes 1 week and can continue for 1 year or more until the scar is strong (Reeder and Martin, 2011).

Common factors affecting wound healing consisting of age, nutrition, steroids, sepsis, and maternal diseases such as anemia, diabetes, and drugs, as well as indications of delivery of SC (Damayanti, 2014). During the wound healing process post-SC requires quality, nutritious nutrition, and enough calories. The food consumed should contain protein, vegetables, and fruits. Nutrition will affect the post-wound healing process SC which 
results in the wound not healing properly or abnormally. Protein is a food substance that is very important to form new tissues, so that it is very well consumed by the postpartum mothers so that post-SC wounds will heal quickly (Said, Taslim and Bahar, 2012).

Snake fish have the highest albumin content compared to other fish. Albumin is one of the important types of protein that the human body needs, every day even in the process of wound healing. Snake fish albumin has much better quality than egg albumin which is commonly used in healing post-surgical patients (Listyanto and Andriyanto, 2009).

From the description above, study is needed to determine post-SC wound status in post-partum women by giving snake fish extract with a dose of $1000 \mathrm{mg}$ for 14 days. For this reason the researcher will conduct a study entitled "The Effect of Snake Fish Extract on Post-SC Injury Status in Postpartum Anemia Mothers”.

\section{SUBJECTS AND METHOD}

\section{Study design}

This was a true experimental study with randomized control group post-test design. This study was divided into 2 groups: intervention and control groups. The study was conducted at $\mathrm{Hj}$. Anna Lasmanah Hospital, Banjarnegara, Central Java, from May to June 2018.

\section{Population and Sample}

The population of this study was all patient with post-SC postpartum anemia in $\mathrm{Hj}$. Annna Lasmanah Hospital Banjarnegara in May to June 2018. The population of all post-partum postpartum mothers was anemia. A sample of 30 study subjects was selected by stratified random sampling, consisted of 15 study subjects in intervention and control groups.

\section{Study Variables}

The dependent variable was post-SC wound. The independent variable was snake fish extract.

\section{Operational Definition of Variable}

Snake fish extract was defined as Pujimin brand fish extract with $1000 \mathrm{mg}$ doses for 14 days. Wound status was defined as a wound assessment that was assessed by redness, edema, ecchymosis, discharge, and approximation. SC indication was defined as an indication of mother that given labor with SC, divided into a risk of a long healing wound and not at risk of a long healing wound.

\section{Study Instrument}

The study instrument in this study were observation sheets for snake fish extract instrumental and REEDA scale for wound status instrumental.

\section{Data Analysis}

The data in this study was analyzed using test for variable confounding with homogeneity, univariate analysis (mean, standard deviation), bivariate analysis (repeated measure ANOVA (test of betweensubjects effect), and repeated measure analysis.

\section{Research Ethics}

This study has obtained a research ethics letter from the Ethics of the Kepmenkes Semarang Polytechnic number: 425/KEPK/Poltekkes-Smg/EC/2018.

\footnotetext{
RESULTS

\section{The Characteristics of Subjects}

The characteristic of subjects showed in table 1 . Table 1 showed that the average of age among the intervention group was $25.27 \%$ in the control group was $26.60 \%$. The homogeneity statistical test showed no differences in age and SC indication, the data were significant in each group (0.411 and 0.345).
} 
Indonesian Journal of Medicine (2018), 3(2): 84-88

https://doi.org/10.26911/theijmed.2018.03.02.04

Table 1. Frequency distribution of the study subjects

\begin{tabular}{lccccccc}
\hline Characteristic & $\begin{array}{c}\text { Intervention } \\
\text { Group } \\
(\mathbf{n = 1 5})\end{array}$ & \multicolumn{2}{c}{$\begin{array}{c}\text { Control Group } \\
(\mathbf{n = 1 5 )}\end{array}$} & \multicolumn{2}{c}{ Total } & p \\
\cline { 2 - 6 } & $\mathbf{N}$ & $\mathbf{\%}$ & $\mathbf{N}$ & $\mathbf{\%}$ & $\mathbf{N}$ & $\mathbf{\%}$ & \\
\hline Age & & & & & & & 0.4111 \\
< 35 years & 1 & 6.7 & 1 & 6.7 & 2 & 6.7 & \\
> 35 years & 14 & 93.3 & 14 & 93.3 & 28 & 93.3 & \\
SC Indication & & & & & & & 0.345 \\
Risk & 2 & 13.3 & 3 & 20 & 5 & 6.7 & \\
No risk & 13 & 86.7 & 12 & 80 & 25 & 93.3 & \\
\hline
\end{tabular}

\section{Univariate Analysis}

Based on Table 2, the average transformation in post-SC wound status was measured 4 times in the intervention group and the control group above for post-SC wound status on day 2 in the intervention

Table 2. Measurement of Wound Status Value

\begin{tabular}{lcccc}
\hline \multirow{2}{*}{ Wound Status } & \multicolumn{3}{c}{ Group } \\
\cline { 2 - 5 } & \multicolumn{2}{c}{ Intervention } & \multicolumn{2}{c}{ Control } \\
\cline { 2 - 5 } & Mean \pm SD & Min-max & Mean \pm SD & Min-max \\
\hline Day 2 & $0.87 \pm 0.35$ & $0-1$ & $1.33 \pm 0.49$ & $1-2$ \\
Day 5 & $0.27 \pm 0.46$ & $0-1$ & $1.07 \pm 0.80$ & $0-2$ \\
Day 12 & $0 \pm<0.01$ & $0-1$ & $0.33 \pm 0.49$ & $0-1$ \\
Day 15 & $0 \pm<0.01$ & 0 & $0.33 \pm 0.49$ & $0-1$ \\
\hline
\end{tabular}

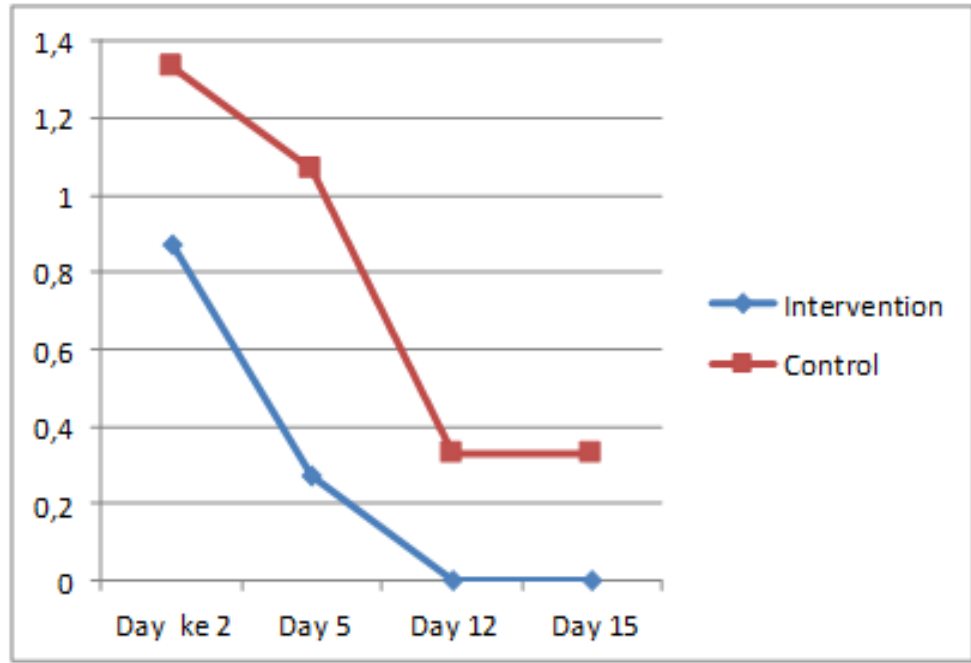

Figure 1. The average of post-SC wound in the intervention and control group

Wound status of anemia post-SC mothers will be shown in Figure 1. Based on Figure 1 on days 2 to 15 for the intervention group with a value of 0.87 and 1.33 for the control group. After giving snake fish extract, on $5^{\text {th }}$ day intervention group was o while in the control group until the $15^{\text {th }}$ day the average wound status was 0.33 . 
status in the intervention group was better than the treatment group.

\section{Bivariate Analysis}

Table 3 showed the differences of wound status post-SC on postpartum anemia

Table 3. Results of Analysis Repeated Measure ANOVA (Test of Between-Subjects Effects)

\begin{tabular}{cccccc}
\hline Source & Type III Sum of Squares & df & Mean & F & p \\
\hline Wound Status & 33.08 & 1 & 33.08 & 76.12 & $\leq 0.001$ \\
\hline
\end{tabular}

\section{Analysis of Differences in Post-SC Injury Status}

Table 4 shows that the results repeated test measure since the measurement of the 2nd day after the intervention obtained

Table 4. Differential Analysis Wound Status between Control Group and Intervention Group

\begin{tabular}{clccc}
\hline Day & \multicolumn{1}{c}{ Group } & Mean & SD & p \\
\hline 2 & Control & 1.33 & 0.49 & 0.006 \\
& Intervention & 0.87 & 0.35 & \\
5 & Control & 1.07 & 0.80 & 0.002 \\
& Intervention & 0.27 & 0.46 & \\
\multirow{2}{*}{12} & Control & 0.33 & 0.49 & 0.013 \\
& Intervention & 0 & 0.00 & \\
& Control & 0.33 & 0.49 & 0.013 \\
& Intervention & 0 & 0.00 & \\
\hline
\end{tabular}

\section{DISCUSSION}

Of a 15 respondents who were given snake fish extract have a good wound status

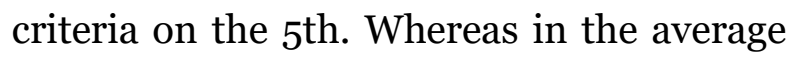
control group on the 12th and 15th days there were still some that were not good. This is in accordance with the study that has been carried out by snake fish extract on wound healing occurs at least on the 6th day and the maximum of the $15^{\text {th }}$ day (Nugraheni and Kurniarum, 2016).

Wound healing is the process of replacing and repairing damaged tissue functions. The wound healing process is influenced by a variety of factors, namely: vascularization, age, anemia, co-morbidities, nutrition, urination, drugs, smoking, $\mathrm{p}<0.005$, which means that there began to be a difference in the measurement of wound status from the first measurement until the $15^{\text {th }}$ day. mother in group intervention and controls. Based on the table 3, $\mathrm{p} \leq 0.001$ which means that there is a difference in post-SC wound status in the intervention and control group. 
and Andriyanto, 2009).

The same study on snake fish extract for wound healing performed by Harianti that snake fish have high albumin content that can accelerate the healing of surgical scars. This has also been done by Prof. Eddy, a total of 2 kilograms of snake fish extract per day are given to a number of patients who have low albumin levels (1.8 $\mathrm{g} / \mathrm{dl}$ ). As a result, after eight days, albumin levels in the patient's blood became normal, i.e. 3.5 to $5.5 \mathrm{~g} / \mathrm{dl}$, and surgical wounds healed without side effects (Harianti, 2011). The results of study by Shafri and Amanan (2012) are effective in wound healing due to the high content of amino acids, such as glycine, fatty acids involved in wound healing from collagen reactions, wound contractions, and return of epithelial tissue to wounds (Ma, M. S. and Mj, A. M, 2012).

\section{REFERENCES}

Agustin R, Dewi N, and Rahardja S. D (2016). Laporan Penelitian Efektivitas Ekstrak Ikan Haruan (Channa Striata) dan Ibuprofen terhadap Jumlah Sel Neutrofil pada Proses Penyembuhan Luka Studi in Vivo pada $\mathrm{Mu}-$ kosa Bukal Tikus (Rattus norvegicus). Dentino 1(1):68-74.

Damayanti, I. P (2014). Factors Associated with Wound Healing Post Sectio Caesarea at Arifin Achmad General Hospital Riau Province in 2013. 2(5):207-210.

Harianti (2011). Ikan Gabus (Channa Striata) dan Berbagai Manfaat Albumin yang Terkandung di Dalamnya. Jurnal Balik Diwa 2(1).

Kulas T, Habek D, Karsa M, and BobicVukovic M (2008). Modified Misgav Ladashmethod for cesarean section: clinical experience. Gynecologic and obstetric investigation 65(4): 222226.

Listyanto, $\mathrm{N}$ and Andriyanto S (2009). Ikan Gabus (Channa Striata), Manfaat Pengembangan dan Alternatif Teknik Budidayanya. Media Akualultur 4(1): 18-25.

Ma, M. S. and Mj, A. M (2012). Therapeutic Potential of the Haruan (Channa striatus): From Food to Medicinal Uses. Malaysian Journal of Nutrition 18(1).

Nugraheni, I and Kurniarum, A (2016). Perbedaan Efektivitas Ekstrak Ikan Gabus dan Daun Binahong terhadap Lama Penyembuhan Luka Operasi Sectio Caesarea pada Ibu Nifas. interest: Jurnal Ilmu Kesehatan 5(2).

Nurani D, Keintjem F and Losu F. N (2015). Faktor-Faktor yang Berhubungan dengan Proses Penyembuhan Luka Post Sectio Caesarea. Jurnal Ilmiah Bidan 3(1).

Reeder, Martin G. (2011). Keperawatan Maternitas. Edisi 18. Jakarta: EGC.

Said S, Taslim N. A, and Bahar, B (2012). Gizi dan Penyembuhan Luka. Jakarta: EGC.

Sofian, A (2011). Sinopsis Obsetri. Jakarta: EGC.

Word Health Organization (2010). WHO European Regional Office Health for all database. Availabe at:http://data. euro. who. int/hfadb. Accessed on May, 10. 